\title{
Self-Assessed Professional Competence of the High School EFL Teachers in Toraja Indonesia
}

\author{
Selvi Panggua ${ }^{1}$, Basri Wello², Baso' Jabu ${ }^{2} \&$ Doris Macdonald ${ }^{3}$ \\ ${ }^{1}$ Toraja Christian University of Indonesia, South Sulawesi, Indonesia \\ ${ }^{2}$ Makassar State University, Makassar, South Sulawesi Indonesia, Indonesia \\ ${ }^{3}$ Northern Illinois University, Deklab, Illinois, USA \\ Correspondence: Selvi Panggua, Toraja Christian University of Indonesia, South Sulawesi, Indonesia. E-mail: \\ panggua.selvi@gmail.com; mbasriwello6@gmail.com; basojabu@gmail.com; dmvm@niu.edu
}

\author{
Received: August 12, 2017 Accepted: September 26, 2017 Online Published: December 23, 2017
}

doi:10.5539/ijel.v8n2p25 URL: http://doi.org/10.5539/ijel.v8n2p25

\begin{abstract}
The teaching of English as a foreign language (EFL) in Toraja is influenced by the quality of teachers from elementary to university level. The Ministry of National Education in Indonesia has stipulated four competencies that should be mastered by teachers: pedagogical competence, professional competence, personal competence, and social competence. The professional competences of foreign language teachers include a knowledge of various aspects of language in English (linguistics, discourse, sociolinguistic and strategic) and mastery of oral and written English language. The purpose of this study is to identify the perceived level of professional competence of high school EFL teachers in Toraja. For this study, 31 high school EFL Teachers in Toraja were chosen randomly from both public and private schools. Data was collected from questionnaires administered in person and by e-mail. The descriptive statistical results of this research show that half of the teachers reported themselves to have only a fair level of professional competence. This suggests the need for in-service training or professional development activities for high school EFL teachers in this region in order to improve their competence and confidence in teaching English.
\end{abstract}

Keywords: high school EFL teachers, professional competence, teachers' competencies

\section{Introduction}

There is a high demand of better English proficiency for people in Toraja-Indonesia. Two important reasons are because Indonesia as one of the Association of Southeast Asian Nations (ASEAN) member, where English is used as one of the communication tools within its members; Toraja as one of the popular international tourist destination in Indonesia should equipt its society with good English proficieny that will enable Torajan people to promote their uniqe culture and the beautiful sceneries to the tourist who come to visit this place.

Strong English proficiency, of course, is influenced by the environments and methods of language teaching and learning. As Rasyid (2015) notes, one important factor that affects the EFL teaching/learning process is the teacher. The teacher is the one who should manage, plan, and make the teaching process interesting and engaging. English language teaching cannot operate effectively without the dedication and effort of such teachers day by day and year by year throughout their careers.

In order to facilitate English language learning, and to reach the requirements of new trends in the field of teaching English as a foreign language (EFL), EFL teachers are expected to update their professional knowledge and competence, and more importantly, to continue this updating through their in-service professional development. (Petties, 2005; Meng et al., 2013).

The Indonesian government has clearly stipulated in the 2007 Teacher Law No. 16 that teachers have to fulfill standards of academic qualifications and teacher competency. The competencies capture teachers' abilities in four general areas namley pedagogical, personal, social and professional competence. Pedagogical competence is about the ability to manage students' learning. Personal competence is the ability of a stable personality, noble, wise and dignified as well as being exemplary learners. Social competence is the ability of teachers to communicate and interact effectively and efficiently with students, fellow teachers, parents/guardians of students and the surrounding community. Professional competence is the ability of mastering the subject matter broadly and deeply. 
This study is focused on one of the EFL teachers' competencies namely professional competence. In Indonesia, this competence is regularly assessed through national tests along with pedagogic competence. However, the World Bank research result found the weakness of Indonesian teacher competence, especially in subject content knowledge (Chang et al., 2014). This is in line with the national test results of the teacher competency test conducted in 2014, the average scores of the selected teachers' subject content knowledge for English was 36.16 (Prihono, 2014). In 2015, the national average score of the competence test was only 53.02, it is lower than the minimum standard competency score of 55 (Maulipaksi 2016). It is also reported that there were $59 \%$ of regencies out of Java province are under the minimum standard of competence, include the Sulawesi Province. The more specific average score of teacher professional competence in South Sulawesi was only 53.83. This average score also below the minimum standard of competence score. While the average score of teachers' competence in Tana Toraja dan Toraja Utara regencies, where this research took place, average score of teachers' competence are also below the minimum standard of competence. For Toraja utara regency, it is only 52.27 as well as Tana Toraja, that is only 52.12. (Data base of Tana Toraja and Toraja Utara Education Offices, 2017). This result of the national competence test (Ujian Kompetensi) for teachers in Indonesia in 2014 and 2015 indicated that teachers in Indonesia, more especially in Toraja still have serious problems with their professional competence.

Regarding the result of the National competence test for teachers in Toraja-Indonesia, the researcher interviewed several EFL teachers in Toraja who indicated that the result cannot assess the entire competencies of teacher because it is only assessing the pedagogical and professional competencies of teacher. They believe strongly that social and personal competencies also play important role in the process of teaching. They reported that this test was not a reflection solely of a teacher's capabilities; for example, there may be some teachers who can answer the test well but cannot teach well or vice versa. In fact, there were some teachers with low test scores who succeeded in leading their students to high achievement in the class. Some stated that "personal approach" to the students in class is the most important.

Considering to the explanation above, this study aims to inverstigate the high school EFL teachers' professional competence level by using a self- assessed questionnaire. It is assumed that teachers themselves know well their competence, which part that they feel low, moderate or high. This self-assessed evaluation will be important to decide which competence that they need to improve in order to make their teaching more interesting and engageging. This assumtion supported by a theory stated by Ross \& Bruce $(2007$, p. 6$)$ that "teacher change is based on the teacher self-asessment within the broader framework of social cognition theory. What matters is not the absolute level of classroom success but teachers' interpretation of experience. Self-assessment contributes to expectation that guide goal setting and effort."

This study aims to answer the research questions as follow: 1). What is the perceived level of professional competence of the high school EFL teachers in Toraja- Indonesia? 2). What kinds of in-service training have been attended by the high school EFL teachers in Toraja? While the objective of this study are to identify the perceived level of professional competence of the high school EFL teachers in Toraja and to describe the kinds of in-service training they have been attended.

\section{Review of Literature}

Professional, pedagogic, social, and interpersonal competencies are required of all teachers in Indonesia. The focus of this study is Professional competence. It deals with what the teacher should know about his/her discipline. In the Ministry of National Education law No. 16 (2007) about the academic qualification standards and teacher competence, teacher professional competence includes: mastering the materials, structures, concepts and the scientific mindsets that supports the teaching subjects; mastering the competency standard and basic competency; developing the teaching learning materials creatively; developing professionalism in sustainable reflective action; and using information and communication technology for self-improvement. The professional competence of English language teachers includes: having linguistic knowledge, discourse, sociolinguistic and strategic levels; mastering the reception and production of all aspects of oral and written English language. Figure 1 describes the EFL teacher professional competence for high school in Indonesia. 


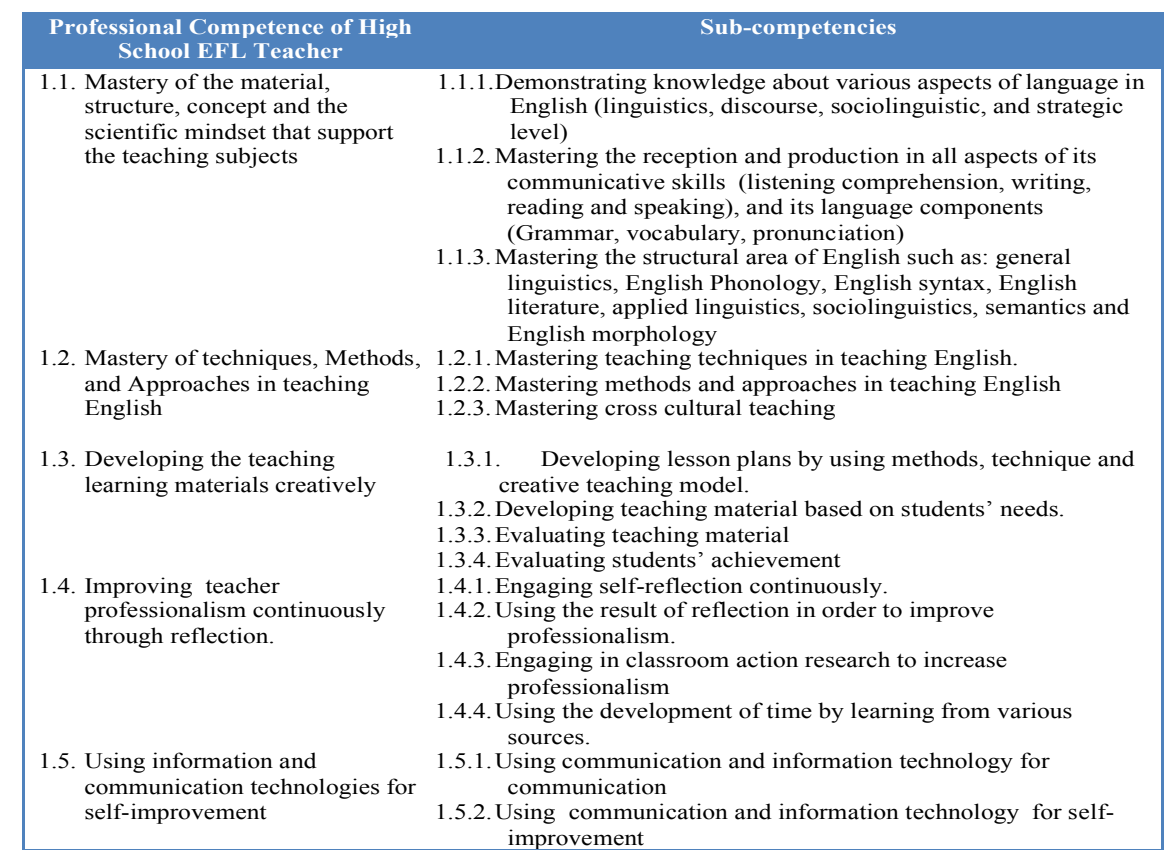

Figure 1. Professional competence of high school EFL teachers in Indonesia

Source: Adapted, modified and translated from The law No.16 (2007) of Educational Ministry of Indonesia.

Based on the explanation on the Figure 1, in this study, the professional competence of EFL teachers are classified into eight competency clusters as follow:

1) The mastery of language aspects in English. This cluster of competency includes three aspects namely linguistics, discourse and sociolinguistics \& strategic.

2) English language proficiency. This competency includes seven sub competency namely listening comprehension, speaking, reading, writing, English grammar, English vocabulary and pronunciation.

3) Academic areas. This competency includes eight sub competencies, they are general linguistics, applied linguistics, English literature, phonology, Syntax, sociolinguistics, semantics and morphology.

4) English teaching techniques. This competency cluster includes twelve sub competencies that divided into two section namely teaching language and teaching strategies. The first section includes techniques of teaching listening comprehension, speaking, reading, writing while teaching strategies includes techniques of teaching grammar, vocabulary, pronunciation, English literature, teaching by using games, puzzle, funny story and songs.

5) Methods and approaches in teaching English. There are seven competencies in this competency cluster namely audiolingual method, TPR, communicative approach, natural approach, grammar translation method, silent way and suggestpedia.

6) Cross-cultural teaching competencies. This cluster includes four competencies namely teaching and integrated culture into the curriculum and classroom, the mastery of information about the culture of English speaking countries, the mastery of cultural aspects affecting foreign language learning and the mastery of regional culture.

7) Other professional competencies. This cluster is divided into four parts includes curriculum planning, evaluation and assessment, material and classroom management and different audiences.

8) Professional development activities. There are six sub competencies in this cluster namely teacher's reflections, improving teaching and learning process based on the result of reflections, doing action research, using computers in foreign language teaching, using internet sources and materials in language teaching and using social medias and language teaching.

The competency clusters above were used as the indicators of professional competence of high school EFL teacher for designing the questionnaire to investigate the teacher participants' level of professional competence. Teacher themselves would rate their professional competence level, which is expected that teacher will change in which self-assessment can be used as one of a mechanism of professional growth that provides avenues for peers 
and change agents to influence teacher practice (Ross \& Bruce, 2007)

\section{Methods}

\subsection{Research Design}

This is a quantitative research study which aims to investigate the self-rated of the professional competence level of the high school EFL teachers in Toraja Indonesia and to identify what kind of training they have been attending.

\subsection{Participants}

Participants were the high school EFL teachers in Toraja-Indonesia academic year 2015/2016. The teachers, who ranged from very novice to very experienced, worked in either vocational, public, or state schools in urban and rural areas. The participants were selected randomly. Ultimately, 31 teachers participated in this research.

\subsection{Instruments}

In collecting data, the researcher used a questionnaire designed to investigate the high school EFL teachers' professional competence based on the the academic qualification standards and teacher competence stated in the Ministry of National Education law No. 16 (2007). There are two parts to this questionnaire. Part I has questions about teachers' professional competence divided into eight cluster competencies as mentioned previously. In this part, respondents choose one of five self-assessed competency levels: Very Poor (VP), Poor (P), Fair (Fair), Good (G), Very Good (VG), in response to each question. Responses were assigned point values from 1 (very poor) to 5 (very good) and were aggregated across all respondents. Part II collects participants' personal/demographic information including a list of trainings they have been attended.

\subsection{Data Analysis Techniques}

Data that collected through the questionnaire then analyzed quantitatively by using descriptive statistics. The anlysis focused on the high school EFL teacher professional competence based on the eight competency clusters addopted and modified from the law No.16 (2007) of Educational Ministry of Indonesia.

\subsection{Research Procedure}

The questionnaire was delivered to the teacher participants directly by visiting them in their MGMP activities (teachers' forum) and some of them were sent by e-mail. From 60 high school EFL teachers, 31 of them completed the questionnaire.

\section{Results}

\subsection{Findings}

In this section the data of the High School EFL teachers' professional competence level in Toraja-Indonesia is presented. Results are presented in the Figure 2 and for each of the 8 clusters of competencies as described in the following tables.

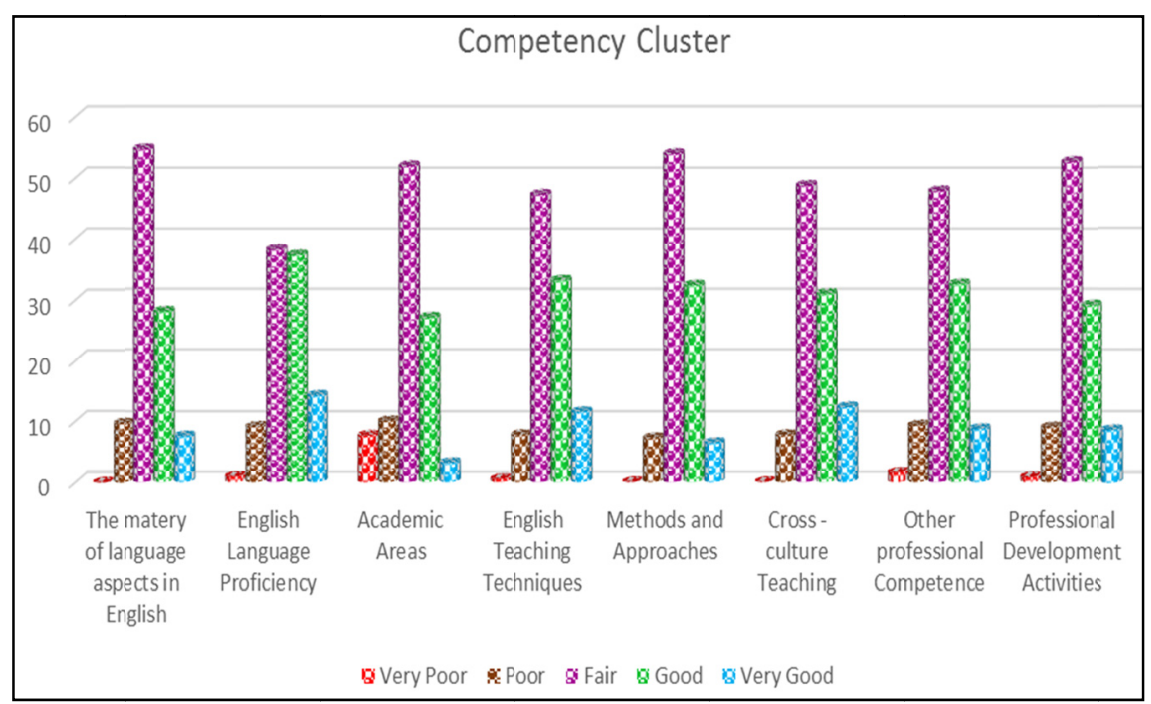

Figure 2. Competence Cluster 


\subsubsection{The Mastery of Language Aspects in English}

This section is addressed by three items in the questionnaire: the mastery of linguistic, discourse, and sociolinguistic and strategic knowledge. Linguistics includes knowledge of grammar, syntax, and phonetics of English, while discourse focuses on the mastery of written or spoken communication in English, and sociolinguistic strategies refers to means to use language in society and in an appropriate sociocultural context. Table 1 presents the results from this section of the questionnaire. The majority of respondents report only a "fair" mastery of all three language aspects, with less than a third of them self-assessing at the "good/very good" level for the other two areas. Keeping in mind that these are the results of self-assessment, it is important to note that, overall, the linguistic aspects of English rated highest, and teachers are least confortable with the discourse and sociolinguistic and strategic knowledge.

Table 1. The mastery of language aspects in English

\begin{tabular}{llllll}
\hline Language Aspects & Very Poor & Poor & Fair & Good & Very Good \\
\hline Linguistics & 0 & $9.68 \%$ & $48 \%$ & $29 \%$ & $12.9 \%$ \\
Discourse & 0 & $9.68 \%$ & $58.1 \%$ & $32.3 \%$ & 0 \\
Sociolinguistics \& Strategic & 0 & $9.68 \%$ & $58.1 \%$ & $22.6 \%$ & $9.7 \%$ \\
\hline
\end{tabular}

\subsubsection{English Language Proficiency}

With respect to general English language proficiency, there were seven items to be assessed. As noted in Table 2 more than half of the 31 respondents reported their competence as "fair" in listening comprehension and speaking. Interestingly, grammar had the widest range, and also the highest "good/very good" rating, while reading, writing and vocabulary also ranked highly. Both of these are more "textbook" skills than "communicative" ones. It may be interesting that "speaking" was rated lower than "pronunciation". It is likely that teachers perceive these skills to be distinct and separably teachable.

Table 2. English language proficiency

\begin{tabular}{llllll}
\hline Language Proficiency & Very Poor & Poor & Fair & Good & Very Good \\
\hline Listening Comprehension & 0 & $9.7 \%$ & $51.6 \%$ & $35.5 \%$ & $3.2 \%$ \\
Speaking & $3.2 \%$ & $6.5 \%$ & $51.6 \%$ & $32.3 \%$ & $6.5 \%$ \\
Reading & 0 & $6.5 \%$ & $38.7 \%$ & $41.9 \%$ & $12.9 \%$ \\
Writing & 0 & $12.9 \%$ & $32.3 \%$ & $38.7 \%$ & $16.1 \%$ \\
English Grammar & $3.2 \%$ & $6.5 \%$ & $29 \%$ & $41.9 \%$ & $19.4 \%$ \\
English Vocabulary & 0 & $9.2 \%$ & $32.3 \%$ & $35.5 \%$ & $22.6 \%$ \\
English Pronunciation & 0 & $12.9 \%$ & $32.3 \%$ & $35.5 \%$ & $19.4 \%$ \\
\hline
\end{tabular}

\subsubsection{Academic Areas}

In the cluster of academic areas, there were eight competency areas included in the questionnaire, as noted in Table 3. It can be clearly seen that the greatest number of respondents report only a "fair" mastery of all the academic areas with one fourth of them self-assessing at the "poor/very poor" level for English syntax. By contrast, however, about a third of them rated general linguistics highest at "good/very good" level. This area are includes questions about teachers' mastery of general and applied linguistic, English literature, phonology, syntax, sociolinguistic, semantic and morphology.

Table 3. Academic areas

\begin{tabular}{llllll}
\hline Academic Areas & Very Poor & Poor & Fair & Good & Very Good \\
\hline General Linguistics & $6.5 \%$ & $9.7 \%$ & $48.4 \%$ & $22.6 \%$ & $12.9 \%$ \\
Applied Linguistics & $6.5 \%$ & $9.7 \%$ & $51 . \%$ & $25.8 \%$ & $6.5 \%$ \\
English Literature & $3.2 \%$ & $9.7 \%$ & $54.8 \%$ & $29 \%$ & $3.2 \%$ \\
English Phonology & $9.7 \%$ & $9.7 \%$ & $51.6 \%$ & $29 \%$ & 0 \\
English Syntax & $9.7 \%$ & $16.1 \%$ & $51.6 \%$ & $22.6 \%$ & 0 \\
Sociolinguistics & $6.5 \%$ & $6.5 \%$ & $54.8 \%$ & $32.3 \%$ & 0 \\
Semantics & $9.7 \%$ & $9.7 \%$ & $48.4 \%$ & $29 \%$ & $3.2 \%$ \\
English Morphology & $9.7 \%$ & $9.7 \%$ & $54.8 \%$ & $25.8 \%$ & 0 \\
\hline
\end{tabular}




\subsubsection{English Teaching Techniques}

Table 4 provides result of the twelve questionnaire items assessing mastery of English language teaching. This cluster is divided here into two sections: teaching language and teaching strategies. In the first section, more than half of participants self-assessed at a "fair" level for teaching reading and speaking techniques and vocabulary rated the highest. While in teaching using different strategies, half the participants self-assessed at a "fair" level, with nearly a half of them placing themselves at the "good/very good" level for teaching English by using games and songs.

Table 4. Teaching techniques

\begin{tabular}{llllll}
\hline Teaching Techniques & Very Poor & Poor & Fair & Good & Very Good \\
\hline Teaching Listening Comp. & $9.7 \%$ & 0 & $38.7 \%$ & $41.9 \%$ & $9.7 \%$ \\
Teaching Speaking & $3.2 \%$ & $6.5 \%$ & $51.6 \%$ & $25.5 \%$ & $12.9 \%$ \\
Teaching Reading & 0 & $3.2 \%$ & $55.2 . \%$ & $38.7 \%$ & $12.9 \%$ \\
Teaching Writing & 0 & $16.1 \%$ & $45.2 \%$ & $29 \%$ & $9.7 \%$ \\
Teaching English Grammar & $3.2 \%$ & $3.2 \%$ & $45.2 \%$ & $32.3 \%$ & $16.1 \%$ \\
Teaching English Vocabulary & 0 & $3.2 \%$ & $32.3 \%$ & $45.2 \%$ & $19.4 \%$ \\
Teaching English Pronunciation & 0 & $16.1 \%$ & $45.2 \%$ & $32.3 \%$ & $9.7 \%$ \\
Teaching English by using Games & 0 & $3.2 \%$ & $51.6 \%$ & $25.8 \%$ & $19.4 \%$ \\
Teaching English by using Puzzle & 0 & $9.7 \%$ & $54.8 \%$ & $29 \%$ & $3.2 \%$ \\
Teaching English Literature & 0 & $9.7 \%$ & $54.8 \%$ & $32.3 \%$ & $3.2 \%$ \\
Teaching English by using Funny Story & 0 & $6.5 \%$ & $51.6 \%$ & $32.3 \%$ & $9.7 \%$ \\
Teaching English by using Songs & 0 & $6.5 \%$ & $51.6 \%$ & $32.3 \%$ & $9.7 \%$ \\
\hline
\end{tabular}

\subsubsection{Methods and Approaches}

Table 5 summarizes the seven items in the cluster for mastery of methods and approaches. Again, for almost all these competences, the most frequent rating was "fair" with more than a half of them self assessing of the "good/very good" level for Total Physical Response and Grammar Translation method. Silent Way and Suggestopedia are rated at a "fair" level. Interestingly, not one of the participants reported having a "very poor" level in any of these methodological competencies.

Table 5. Methods and approaches

\begin{tabular}{llllll}
\hline Methods and Approaches & Very Poor & Poor & Fair & Good & Very Good \\
\hline Audiolingual method & 0 & $6.5 \%$ & $51.6 \%$ & $32.3 \%$ & $9.7 \%$ \\
Total Physical Response & 0 & $6.5 \%$ & $29 \%$ & $35.5 \%$ & $29 \%$ \\
Communicative Approach & 0 & $6.5 \%$ & $41.9 \%$ & $38.7 \%$ & $12.9 \%$ \\
Natural Approach & 0 & $9.7 \%$ & $54.8 \%$ & $25.8 \%$ & $9.7 \%$ \\
Grammar Translation Method & 0 & $6.5 \%$ & $32.3 \%$ & $41.9 \%$ & $19.4 \%$ \\
Silent Way & 0 & $12.9 \%$ & $58.1 \%$ & $25.8 \%$ & $3.2 \%$ \\
Suggestopedia & 0 & $6.5 \%$ & $77.4 \%$ & $12.9 \%$ & $3.2 \%$ \\
\hline
\end{tabular}

\subsubsection{Cross-cultural Teaching}

There are four items in the competence cluster for mastery of cross-culture teaching, as displayed in table 6 . The findings indicate that more than half of the participants report only "fair" mastery of cross-culture teaching, with nearly a half of them self-assessing at the "good/very good" level for the category of teaching and integrating culture into the curriculum and the classroom. More than one third of the participants self-assessed their mastery at "good/very good" level for information about the culture of English countries and their regional culture. Surprisingly, the numbers are identical for both competences.

Table 6. Cross-culture

\begin{tabular}{|c|c|c|c|c|c|}
\hline Cross-culture & $\begin{array}{l}\text { Very } \\
\text { Poor }\end{array}$ & Poor & Fair & Good & Very Good \\
\hline Teaching and Integrating Culture into the Curriculum and the classroom & 0 & $6.5 \%$ & $51.6 \%$ & $33.3 \%$ & $9.7 \%$ \\
\hline The mastery of information about the culture of English speaking countries & 0 & $6.5 \%$ & $54.8 \%$ & $32.3 \%$ & $6.5 \%$ \\
\hline The mastery of cultural aspects affecting foreign language learning & 0 & $6.5 \%$ & $54.8 \%$ & $32.3 \%$ & $6.5 \%$ \\
\hline The mastery of regional culture & 0 & $9.7 \%$ & $54.8 \%$ & $32.3 \%$ & $3.2 \%$ \\
\hline
\end{tabular}




\subsubsection{Other Professional Competencies}

The fourteen items in Other Professional Competencies cluster group into four parts: curriculum planning; evaluation assassment; materials and classroom management; and different audiencies. The majority of respondents report only a "fair" mastery of all the thirteen aspects of this cluster, with the exception of language laboratory use, where almost two-thirds assess their competency to be very poor or poor. In the first group of items, more than a half self-assessed at "good/very good" level for the three aspects of curriculum planning altough, about $9 \%$ said to have "poor/very poor" level mastery for curriculum development. Furthermore, in the evaluation/assessment competence, less than a half repondents reported having "good/very good" mastery level. A large number of participants rated their competence as "good/very good" mastery for Preparing Teaching Material and Classroom Management. Additionally, in terms of audience, the respondents rated themselves as most competent to teach children, a little less competent in teaching English for specific purposes, and least competent in teaching for business and technology.

Table 7. Other professional competence

\begin{tabular}{|c|c|c|c|c|c|}
\hline Other Professional Competence & Very Poor & Poor & Fair & Good & Very Good \\
\hline \multicolumn{6}{|l|}{ Curriculum Planning } \\
\hline Curriculum Development & $3.2 \%$ & $6.5 \%$ & $48.4 \%$ & $32.3 \%$ & $9.7 \%$ \\
\hline Designing Lesson Plan & 0 & $6.5 \%$ & $51.6 \%$ & $32.3 \%$ & $9.7 \%$ \\
\hline Testing constraction, administration, and scoring & 0 & $6.5 \%$ & $48.8 \%$ & $32.3 \%$ & $9.7 \%$ \\
\hline \multicolumn{6}{|l|}{ Evaluation/Assessment } \\
\hline Evaluating and Mentoring Students Progress & 0 & $6.5 \%$ & $51.6 \%$ & $32.3 \%$ & $9.7 \%$ \\
\hline \multicolumn{6}{|l|}{ Materials and classrom Management } \\
\hline Preparing teaching material & 0 & $6.5 \%$ & $48.8 \%$ & $29 \%$ & $16.1 \%$ \\
\hline Using Audio Visual aids & 0 & $6.5 \%$ & $51.6 \%$ & $32.3 \%$ & $6.5 \%$ \\
\hline Using Language laboratory & $19.4 \%$ & $41.9 \%$ & 0 & $22.6 \%$ & $3.2 \%$ \\
\hline Varying classroom activities & 0 & $6.5 \%$ & $51.6 \%$ & $35.5 \%$ & 6.5 \\
\hline Principle of language pedagogies & 0 & $6.5 \%$ & $51.6 \%$ & $35.5 \%$ & $6.5 \%$ \\
\hline Text book and material selections & 0 & $3.2 \%$ & $51.6 \%$ & $35.5 \%$ & $9.7 \%$ \\
\hline Classroom Management & 0 & $6.5 \%$ & $48.4 \%$ & $35.5 \%$ & $9.7 \%$ \\
\hline \multicolumn{6}{|l|}{ Different Audiences } \\
\hline Teaching English for specific purposes & 0 & $6.5 \%$ & $54.8 \%$ & $29 \%$ & $9.7 \%$ \\
\hline Teaching English to children & 0 & $6.5 \%$ & $48.4 \%$ & $35.5 \%$ & $9.7 \%$ \\
\hline Teaching English for bussiness and technology & 0 & $12.9 \%$ & $54.8 \%$ & $32.5 \%$ & 0 \\
\hline
\end{tabular}

\subsubsection{Professional Development Activities}

For the six items in the Professional Development Activities cluster, the majority of respondents report only a fair mastery (Table 8). Almost a third of them self-assesed at the "poor/very poor" level for Doing Action Research. Nevertheless, nearly a half of them rated their mastery at "good/very good" level for using social media in Language Teaching and using internet sources.

Table 8. Professional development activities

\begin{tabular}{|c|c|c|c|c|c|}
\hline Professional Development Activities & Very Poor & Poor & Fair & Good & Very Good \\
\hline Teacher's reflection & 0 & $9.7 \%$ & $54.8 \%$ & $29 \%$ & $6.5 \%$ \\
\hline Improving teaching and learning process based on his/her reflection & 0 & $9.7 \%$ & $51.6 \%$ & $32.3 \%$ & $6.5 \%$ \\
\hline Doing action research & $4.8 \%$ & $16.1 \%$ & $45.2 \%$ & $32.3 \%$ & $3.2 \%$ \\
\hline Using computers in foreign language teaching & 0 & $6.5 \%$ & $54.8 \%$ & $29 \%$ & $9.7 \%$ \\
\hline Using internet sources and materials in language teaching & 0 & $6.5 \%$ & $48.4 \%$ & $29 \%$ & $16.1 \%$ \\
\hline Using social medias in language teaching & 0 & $6.5 \%$ & $51.6 \%$ & $32.3 \%$ & $9.7 \%$ \\
\hline
\end{tabular}

\subsection{Discussion}

EFL teachers' professional competence has to be of critical concern for teachers themselves. In the process of assessing their professional competencies, the EFL teachers in this study were challenged to critically review their own mastery of EFL teaching via observing, analyzing, and judging their competencies based on the statements in the questionnaire. The main reason for EFL teachers to assess their own professional competencies 
is to investigate self-perceptions toward their EFL teaching skills in order to improve their competencies. They will initiate to make a change in their teaching quality by realizing their own level of professional competence. Ultimately, this self-reflection can aid in their deciding what kind of in-service training they need in order to improve their teaching quality.

The findings in this study provide evidence that, in the mastery of language aspects, methods and approaches, and cross-cultural teaching clusters, none of the respondents rated their competence as "very poor." For these competencies, there was also limited self-assessment as "poor." In fact, the highest "very good" scores are found in clusters that address English teaching techniques, cross-cultural teaching, and English language proficiency. In considering how to implement professional training, we may want to consider that teachers may not need extensive additional support in these areas.

In the academic areas competency, the participants assessed themselves at the highest "very poor" and "poor" scores as well as the lowest "good" and "very good" scores. Referring to this fact, it might be the consideration that teachers need support in this area. They may need additional training on the mastery of English syntax, phonology, morphology and phonology. However, these ranging scores might also be attributed to the lands of pre-service training (such as college course work) that teachers received.

Additionally, in the English language proficiency cluster, the participants tend to rank themselves highly in the "text book skills" rather than in "communicatives areas." This might be a reason why many secondary students in Indonesia struggle to be able to use English as a communication tool; they are rarely taught how to use the language and are often reluctant to speak out of fear of making mistakes in using grammar. Teachers tend to emphazise teaching text book skills both for classroom efficiency and for preparing students for tests. Lamb (2007) noted in his own observations of over 30 lessons, that the majority of classes consisted of a series of teacher-directed oral or written exercises closely based on the textbook with little variety of format and virtually no communicative use of language (p. 771). This finding can be an implication that EFL teachers in Toraja-Indonesia need additional support in teaching and assessing the communciative skills of their students. Non-native speakers EFL teachers rarely use English for instructional purposes, rather use Indonesian or local language in the language teaching. They may have had few native speaker models in how to maintain communication and therefore less experience themselves in with limited native speaker interaction of their own, teachers may feel less confident or less able to teach communication skills, even if their skills are objectively rated to be good/very good (e.g., TOEFL, IELTS score).

In terms of English teaching techniques, teachers seem to be familiar with teaching grammar and vocabulary as well as in teaching using games, but a few respondents report "very poor" competence teaching listening comprehension. As mentioned perviously, teachers have less experience in using techniques and strategies to maintain coversation and oral communication in their class. This can also be a consideration that they may still need support in this area. The teachers' perception of pronunciation and speaking skills to be distinct is reflective of how these language skills are presented in the EFL curriculum.

In the methods and approaches competency, teachers report familiarity with using Total Physical Response in teaching EFL. This method is perceived as enjoyable, fast-paced, and easy to implement in the classroom, especially for kinaesthetic learners who are required to be active in the classroom and for younger learners, this method is effective. In addition, it is believed to involve both left and right-brained learning (Larsen et al., 2011). By contrast, the participants report "fair" competence in using Silent Way and Suggestopedia methods, two methods that require extensive training and detailed, consistent, and specialized implementation techniques and materials.

In cross-cultural teaching competence, it is interesting that teachers perceived themselves to have higher level in the mastery of information about the culture of English speaking countries than the mastery of their own regional culture. This could be because the participants supposed that the regional culture here means the "Torajan culture," where most of the younger generation there think that they do not know their own culture well. For this reason, this is might be an interesting research project for further investigation.

Finally, more than a half of the participants report having "poor/very poor" competence in using a language laboratory. While language laboratories have changed radically in the last five decades, it may be that teachers rarely practice using a language laboratory or they think that language laboratory is only a room with tape recorders. However, such facilities are now multi-media centers with internet connectivity. It might be interesting to further investigate what sorts of facilities these teachers have handy and what training they might or might not have received in using them. This may be interesting in light of the fact that, in responding to a different question, they report "very good" competency in using internet sources and materials in language teaching. 


\section{Conclusion}

EFL teachers in Indonesia are required to have knowledge about various aspects of English (linguistics, discourse, sociolinguistic, and strategic) and mastery of oral and written English language. However, the results of this research show that half of the sample of high school EFL teachers in Toraja-Indonesia reported themselves to have only fair levels of professional competence which is assessed in eight clusters of competencies, while fewer than one third of the remainder of them perceived themselves to have good (or better) levels of competence. There may be a number of reasons for this result: perhaps the professional development activities provided by the Indonesian's Ministry of Education has not met the teachers' needs to update their professional knowledge and competence, to expand and reach the requirements of new trends in the field of teaching English as a foreign language; Not all the teachers have the same opportunity to attend professional development activities especially those from rural areas, where the school budget is not adequate to send more than one or two representatives; sometimes those who attend programming are not able to share their experience with their colleagues, even within their own schools.

Results from the survey reported in this research indicate that high school EFL teachers in Toraja need opportunities for improvement for their professional competencies. Although the research reported here is the result from a survey, it is suggested a training model for improving high school EFL teachers' professional competence based on the teachers' self-assessment result. This study result also shows which parts of teachers' professional competencies that they need to improve. It also suggests the need for a new in-service training model. One model we might consider is a peer-coaching teaching model that connects the collaborative learning of EFL teacher or other professional development activities for high school EFL teachers in Toraja-Indonesia in order to improve their competence in teaching English.

\section{Acknowledgments}

The researcher addresses her thanks to The Ministry of Research, Technology and Higher Education of Indonesia for the financial support (PKPI Program 2016), State University of Makassar, Northern Illinois University, and Toraja Christian University of Indonesia.

\section{References}

Burns, A., \& Edwards, E. (2014). Introducing Innovation Through Action Research In An Australian National Programs: Experiences And Insights. In D. Hayess (Ed.), Innovations in the Continuing Professional Development of English Language Teachers. London, UK. British Council. Retrieved from www.britishcouncil.org

Butler, Y. G. (2004). What level of English proficiency do elementary school teachers need to attain to teach EFL? Case studies from Korea, Taiwan, and Japan. TESOL Quarterly, 38, 245-278. https://doi.org/10.2307/3588380

Davidson, G., Dunlop, F., Soriano, D. H., Kennedy, L., \& Phillips, T. (2012). Going forward: Continuing Professional Development for English Language Teachers in the UK: English Agenda; British Council. Retrieved from http://englishagenda.britishcouncil.org/accessed

Departemen Pendidikan Nasional [National Ministry of Education]. (2005). Undang-Undang No. 14 tahun 2005 tentang Guru dan Dosen. Jakarta.

Departemen Pendidikan Nasional [National Ministry of Education]. (2007). Peraturan Menteri Pendidikan Nasional Nomor 16 Tahun 2007, tentang Standar Kualifikasi Akademik dan Kompetensi Guru, Jakarta: Depdiknas.

Eslami, Z. R., \& Fatahi, A. (2008). Teachers' Sense of Self-Efficacy, English Proficiency, and Instructional Strategies: A Study of Nonnative EFL Teachers in Iran. TESL-EJ, 11(4), n4.

Guskey, T. R. (2002). Professional development and teacher change. Teachers and Teaching: Theory and Practice, 8(3), 381-391. https://doi.org/10.1080/135406002100000512

Jalal, F. (2005). Teachers' quality improvement in Indonesia: New paradigm and milestones. Jakarta: Departemen Pendidikan Nasional.

Kennedy, A. (2005). Models of Continuing Professional Development: A Framework for Analysis. Journal of In-Service Education, 31(2), 235-250. https://doi.org/10.1080/13674580500200277

Komur, S. (2010). Teaching knowledge and teacher competencies: A case study of Turkish preservice English teachers. Teaching Education, 21(3), 279-296. https://doi.org/10.1080/10476210.2010.498579 
Lamb, M. (2007). The impact of school on EFL learning motivation: An Indonesian case study. Tesol Quarterly, 757-780. https://doi.org/10.1002/j.1545-7249.2007.tb00102.x

Larsen-Freeman, D., \& Marti, A. (2011). Techniques and Principles in Language Teaching (3rd ed.). Oxford University Press, USA.

Naaim, M. Y. (2015). Challenges in Education Toward the Realization of ASEAN Community. General Lecture. Director General Colombo Plan Staff College for Technician Education. Retrieved from www.site.rmutt.ac.th/cpscworkshop/materials/sp.pdf

Rasyid, M. A. (2015). Teaching Material of TEFL Methods. English Education Department of Makassar State University.

Ricahrds, J. C., \& Farrell, T. S. C. (2005). Professional Development for Language Teacher: Strategies for Teacher Training. New York: Cambridge University Press. https://doi.org/10.1017/CBO9780511667237

Ross, J. A., \& Bruce, C. (2017). Teacher self-assessment: A mechanism for facilitating professional growth (PDF Download Available). Retrieved from https://www.researchgate.net/publication/222538288_Teacher_self-assessment_A_mechanism_for_facilitati ng_professional_growth

Sikki', A., Asfah, R., Hamra, A., \& Noni, N. (2013). The Competence of Primary School English Teachers in Indonesia. Journal of Education and Practices, 4(11). Retrieved from www.iiste.org

Simegn, B. (2014). EFL Teacher Self- Initiated Professional Development: Perceptions and Practices. Academic Journals: Educational Research and Reviews (online), 9(21). Retrieved from http://www.Academicjournals.org/ERR/

Syafar, A. (2013). Self-assessment of Certified EFL Teachers in Central Sulawesi on Their Professional Competence. Educational Social Science, 1(3). Retrieved from http://journal.um.ac.id/index.php/jph/article/view/4140

Tarakawita, H. (2011). Teacher Certification in Indonesia. Retrieved from http://www.researchgate.net/publication/251442703_Teacher_Certification_in_Indonesia

UNESCO. (2006). Decentralization of education in Indonesia Teacher and resource management in the context of decentralization. Paris: UNESCO.

USAID Indonesia. (2009). Teacher Education and Professional Development in Indonesia. A Gap Analysis. Retrieved from pdf.usaid.gov/pdf_docs/Pnads282.pdf

Wello, B. (1999). Assessment of the in-service Training Needs of the High School English Teachers. (Unpublished doctoral dissertation). Hasanuddin University of Indonesia, Ujung Pandang (Makassar), South Sulawesi, Indonesia.

\section{Copyrights}

Copyright for this article is retained by the author(s), with first publication rights granted to the journal.

This is an open-access article distributed under the terms and conditions of the Creative Commons Attribution license (http://creativecommons.org/licenses/by/4.0/). 